\title{
THE STOCKHOLM CONFERENCE OF I9I7
}

In 1917 , in the midst of war, the internationalist ideals of the old Second Socialist International came close to achieving an unparalleled diplomatic triumph of non-governmental initiative by bringing together responsible political leaders of the left from the countries of opposing belligerents to discuss peace terms with neutrals on neutral ground at Stockholm.

Unlike its successor, the 1914-1918 war was not waged on either side with the uncompromising policy of "unconditional surrender"; but a war propaganda of hatred largely dominated the thinking of peoples and governments. Looking back, it is, therefore, a remarkable tribute to the level-headedness of the statesmen of that generation that the coming together of patriotic men - albeit politically likeminded - to work out a programme for peace could even have been contemplated while the battle still raged. The probability that without the advent of the First Russian Revolution in the spring of 1917 such a meeting would indeed have been unimaginable, does not make less remarkable what nearly occurred.

The unofficial peace conference at Stockholm never took place; and the sorry history after Versailles, and the isolation of Russia after the October Revolution, are known to all. But the story of Stockholm - its preparation, rise in favour, and the ultimate failure even to assemble, point to one of the great "might-have-beens" of recent history: could a "paix des braves" based on social-democratic principles have been offered to governments and stopped the bloodshed, bringing peace and confidence between the Powers - America and Russia as well as European? (Europe was ripe for a negotiated peace in 1917 , but it is the maddening tragedy of international politics that governments miss opportunities to negotiate in equality in order to be able to negotiate from strength - which ultimately means that one side at least has to negotiate under duress.) Of more direct interest to pragmatic historians is, however, the light (though perhaps only a sidelight) that it casts on the political motives and movements which 
then developped as cross-currents to the tide of war and flourished in the post-war years. Moreover, the period we have to discuss is that of the great watershed of Russian - and world - history between March and October, 1917; and the position of Russia is central to our theme.

The story in outline is thus: the terrible winter of $1916-1917$ brought war-weariness to alle the belligerents and gave impetus to many private initiatives towards peace, of which those of Baron Lancken, Prince Sixtus, and Pope Benedict XV are perhaps the best known; and it made way directly to the First Russian Revolution. When the revolution broke out, the governments of both the Entente and Central Powers, for their separate reasons, at once the made contact with the new Russia - and for this purpose they used men of the left who were thought most likely to gain influence in Petrograd. At the same time the rump of the pre-war Socialist International set out to exploit these events to achieve a socialist peace. By the late spring, governments on either side in the war were weighing the advantages of giving their Socialist parties free reign to confer on peace terms: from then on to the summer, the idea of a Socialist peace conference - known throughout as "Stockholm" - gained ground with the British and German authorities, among the patriotic Socialists in all countries, and in Petrograd. The opponents to Stockholm in that summer were unlikely enough help-mates: the French and American Governments - and the Bolsheviks. Lloyd George abandoned Stockholm in July and it then lost any hope of the blessing of the Entente powers; and as the summer progressed Lenin's influence grew in Petrograd and doomed whatever hope for Stockholm still remained.

Before looking more closely at these events we must first consider quickly what happened to European Socialism with the coming of war in 1914 .

Inevitably, the Second International - which had laid claim to direct the policies of Socialist parties in all countries - disintegrated as soon as war broke out. Its principles and ideals were thrown into confusion from which, in each belligerent country, there emerged three distinct groups: (I) the "majority" which supported the national war effort, (2) the "centre" which had qualms about the war, and (3) the "internationalists", out-and-out pacifists and full-blooded revolutionaries. In addition there were the Socialists of neutral countries, all of whom wanted their respective nations to remain neutral, but who varied in their attitude vis-à-vis the belligerents.

After the war began, the first efforts to try to goad the disrupted International into action came from the neutrals, but were without avail. The only positive action possible was the moving of the B.S.I. 
(Bureau of the Socialist International) from occupied Belgium to The Hague and the addition of three Dutch members to the Executive Committee to guarantee its neutrality to the Socialists of the Central Powers. Huysmans, the Belgian Secretary of the B.S.I., there adopted a cautious policy for re-establishing relations between belligerent Socialists first by organising conferences, respectively, of the Socialists of Allied countries, of neutral countries, and of the Central Powers, and then by holding separate meetings with representatives of all parties.

The internationalist Socialists, however, sought a more active policy and created the I.S.C. (International Socialist Commission) at Zimmerwald to spur the B.S.I. on. In this organisation Lenin and the left-wing, revolutionary Socialists formed a group - the Left Zimmerwaldians which at Kienthal in 1916 made clear their desire to break completely with the right-wing Socialists. But neither the B.S.I. nor the I.S.C. could get the "majority" parties of the belligerent countries to develop an interest in peace or in peace terms until the war-weariness of the winter of 1916-1917 turned the thoughts of all - Socialist and non-Socialist - towards peace.

The First Russian Revolution of the spring of $\operatorname{Ig}^{1} 7$ shifted the focal point of interest in Europe northwards and brought new hope and spirit, not only to Socialists, but after the initial shock, also to the Entente which felt that the new régime might carry on the war with greater vigour. The revolution made it possible for the Entente, after the United States had entered the war in April, to claim a "crusade for democracy and against absolutism" and to hope that social unrest might lessen. For the Central Powers there was hope of a separate peace with Russia, while Germany's increasingly successful submarine campaign crippled France's allies in the West. Everyone felt that the war would soon end, and interest in and discussion of peace terms grew.

The primary aim of the Entente was to keep Russia in the war; and it seemed possible that the new Russian Government might conclude a separate peace. If this happened German pressure on the Western Front would increase, possibly before the arrival of American troops and supplies in Europe. Thus the delight of the Entente at enjoying the support of both a democratic Russia and the United States was tempered by the fear of a separate Russian peace, of the continued and considerable German pressure on the Western front, and of the menace of the submarine campaign. The situation in Petrograd after the First 
Russian Revolution was fundamentally unstable and could not last. The Entente, the Central Powers, and Lenin, all recognised this, and each made efforts to change it to his own advantage. The outcome of the struggle of the various forces of the Russian revolution was thus of vital importance to all. It was in their efforts to support the moderates, who favoured continuing the war, that the Entente Governments first became interested in the Stockholm conference.

The first to make a definite move was the British Ambassador in Petrograd, Sir George Buchanan, on is March. He suggested that British Labour leaders should be asked to telegraph a message to the Duma Labour leaders, Kerensky and Chkheidze, expressing confidence that Russian Labour would support the "free peoples fighting German despotism, pointing out that every idle day [would spell] disaster to their brothers fighting in the trenches, and that victory to Germany would bring disaster to all classes of the Allies." Henderson, the Labour Party's representative in the British War Cabinet, drafted the reply along the lines desired. ${ }^{1}$ And later other messages were sent by labour leaders in the other Entente countries, including one from Gompers after the United States' entry into the war. ${ }^{2}$

The Entente Governments also felt that it would be useful to send "labour deputations" of Socialists who supported the war to visit Russia. Some delegates went as representatives of their governments, and some as representatives of their parties, but all were encouraged in their journey.

The French and British parties were the first to send delegations. The Socialist deputies, Moutet, Cachin, and Lafont, went under the auspices of "La Ligue des Droits de l'Homme", as a parliamentary delegation paid for from a parliamentary fund for propaganda, open to all parliamentary missions. They wanted this amount of official status, but not to be actually a government delegation bound by French policy. ${ }^{3}$

On 26 March, when Henderson reported to the British War Cabinet that representatives of the S.F.I.O. were going to Petrograd via England "with the authority and consent of the French Committee of Foreign Affairs" to persuade the Russian Socialists to continue the war, he was asked to make up a suitable British Labour delegation to

1 Lloyd George, David, War Memoirs of David Lloyd George, Ivor Nicholson and Watson, London, I933-6, Vol. IV, pp. 1883-5.

2 Cumming, C. E., and Walter W. Petit, Russian-American Relations: March, I 917

- March, I920: Documents and Papers, Harcourt, Brace and Howe, New York, 1920, pp. I4-16.

sourgin, Hubert, Le Parti contre la Patrie, Librairie Plon, Paris, 1924, pp. 208-I I. 
accompany the French one, ${ }^{1}$ and it was agreed to pay the expenses out of the vote for Diplomatic and Consular Services. ${ }^{2}$

These two delegations arrived in Petrograd on I 3 April, but their visits were not a success. The delegates did their best to carry out their duty as they saw it, but were handicapped by language difficulties and a different approach to things. They failed to win over even the moderate Socialists and were considered "lackeys" 3 of their governments. ${ }^{4}$ On the other hand, though the views of the British delegation were apparently unaffected by their reception, the French delegation seems to have been moved by Russian revolutionary enthusiasm and by the hardships that the Russians had to face. Cachin was sufficiently impressed to agree that the Alsace-Lorraine question ought to be submitted to a plebiscite in order to facilitate peace negotiations. (Paléologue, the French Ambassador to Russia, was furious.) ${ }^{5}$ The French delegation also came to favour an international Socialist conference on peace terms which, it seemed to them, was essential if Russia were to be induced to stay in the war. War-weariness was far greater than they had supposed, and the Russians appeared readier to fight for peace than to fight for victory.

The failure of these visits to influence Russian opinion is shown by the fact that on Io May, Miliukov, the Russian Foreign Minister, at the request of the Soviet sent a telegram to the Italian, British, and French Governments asking them respectively to allow representatives of the Italian Socialist Party, the British Independent Labour and Social-Democratic Parties, and the opposition within the French Socialist Party - all anti-war Socialists and members of the Zimmerwald movement (to which Mensheviks, Bolsheviks, and Social Revolutionaries, but not Kerensky's Labour Party, all belonged) - to come to Russia. Though the request was not formally refused, it was not

\footnotetext{
${ }^{1}$ Lloyd George, op.cit., Vol. IV, p. 1885; Trades Union Congress, Report of the Proceedings at the Forty-Ninth Annual Trades Union Congress Held in the Palace Hall, Blackpool, on September 3 rd to 8th, 1917, T.U.C. and Parliamentary Committee, London, 1917, p. 19r.

The Parliamentary Debates (Official Report): Fifth Series: House of Commons (hereafter called "Parliamentary Debates"), His Majesty's Stationery Office, London, Vol. XCVI, p. 888.

3 This more recently familiar epithet is used by Bruce Lockhart in describing the Russian attitude to the missions.

- Lockhart, R. H. Bruce, Memoirs of a British Agent, Being an Account of the Author's Early Life in Many Lands and of His Official Mission to Moscow in 1918, Putnam, London, I932, p. I83; Price, Morgan Philips, My Reminiscences of the Russian Revolution, George Allen and Unwin, Ltd., London, x92 1, pp. 19-20.

5 Paléologue, Maurice, An Ambassador's Memoirs, translated by F. A. Holt, Hutchinson and Co., I925, Vol. III, pp. 299-300.
} 
granted. ${ }^{1}$ Later, however, at the instigation of Henderson and Buchanan, the British Government gave representatives of the I.L.P. and B.S.P. permission to go to Russia, but the Seamen's Union refused to take them. ${ }^{2}$

On 22 April, Albert Thomas arrived in Petrograd accompanied by many secretaries and officials, and with authority to replace Paléologue, the French Ambassador. The French Government hoped that as a pro-war and government Socialist he would be more acceptable to the Russians and have greater influence over them than Paléologue, a Miliukov supporter. Albert Thomas made friends with Buchanan, and with him stimulated the loyalty of Kerensky to the Entente. He also got the Petrograd Soviet to adopt a resolution in favour of the restitution of Alsace-Lorraine to France, and to agree to reparations, in return for which he accepted the phrase "peace without annexations and contributions". At the time this seemed a great service to the Entente, but the composition of the Soviet changed, so it made little real difference to events. ${ }^{3}$

On I 8 May, a Belgian delegation arrived: Vandervelde, de Brouckère and de Man. Vandervelde said that they went to Petrograd on a sort of pilgrimage to a new Jerusalem; de Man that they were sent by the Belgian Government. ${ }^{4}$ In any case they completely supported their government's policy, and themselves proposed, first to join the Socialists from the other Entente countries to combat any Russian tendencies to seek a separate peace or a peace at any price; second, to bring the case of Belgium and of the Belgian working men before the Russian Socialists, appealing to their solidarity in the struggle against German Imperialism; and, third, to consider what attitude to adopt towards the idea of holding a Socialist conference on peace terms at Stockholm. ${ }^{5}$

Labriola, Ramionda, Cappa, and Lerda, from the Italian Interven-

${ }^{1}$ Lloyd George, op. cit., pp. $1887-9$.

2 Buchanan, Sir George, My Mission to Russia and Other Diplomatic Memories, Cassell and Co., Ltd., London, I 923 , Vol. II, pp. 142-7; Brockway, Archibald Fenner, Socialism over Sixty Years: The Life of Jowett of Bradford (1884-1944), George Allen and Unwin Ltd., London, 1944, Pp. 155-6; Independent Labour Party Report of the Annual Conference Held at Leicester, Aptil, 1918 (hereafter called I.L.P., "Annual Report, 1918"), I.L.P., London, I918, p. 10.

3 Lockhart, op. cit., pp. 184-5; Paléologue, op.cit., Vol. III, pp. 328-30.

- Vandervelde, Emile, Souvenirs d'un militant socialiste (hereafter called Vandervelde, "Souvenirs..."), Les Editions Denoël, Paris, 1939, p. 227; de Man, Henri, Cavalier Seul, 45 Années de Socialisme européen, Les Editions du Cheval Ailé, Genève, 1948, p. 93.

5 Vandervelde, Emile, Three Aspects of the Russian Revolution (hereafter called Vandervelde, "Three..."), translated by Jean E. H. Findlay, George Allen and Unwin, Ltd., London, 1918, p. 7 and p. 199. 
tionist Left and Reformist Parties, also arrived in Petrograd in May. ${ }^{1}$ And on 2 June, Henderson arrived accompanied by George Young, a secretary of the War Cabinet. Like Albert Thomas, Henderson had powers to replace his country's Ambassador. However, after six weeks he concluded that Buchanan was doing as good a job as could be done, declined the appointment, and returned to London.

The last of the Entente delegations to Russia was the Root Mission from the United States, which was an official mission of the government named after Elihu Root, who headed it as an Ambassador extra-ordinary. Charles Edward Russell, a pro-war Socialist, and James Duncan, the second vice-president of the A.F. of L. went with it. ${ }^{2}$

$$
* * *
$$

Though the Central Powers, as enemy countries, obviously could send no direct mission to Russia, they saw in the Russian Revolution a hope for separate peace on the Eastern Front. Zimmermann, the German Secretary of State, was, therefore, very pleased when the S.P.D., through Scheidemann and Parvus (Dr. Helphand) suggested getting a message on peace terms carried to the Russian Socialists. Zimmermann considered certain frontier rectifications a necessary part of any peace terms, but Scheidemann and Parvus, while declaring their willingness to be cautious, insisted on the S.P.D. view of peace immediately rather than any terms which might prolong the war.

Scheidemann and Parvus proposed to send the S.P.D. message to Russia through Borgbjerg, a Danish Socialist who was going to Petrograd to ask the Russian Socialists to join in an appeal for an international Socialist conference. Accordingly, Scheidemann and Parvus, together with Ebert and Gustavus Bauer, of the Trade Unions, went to Copenhagen where they persuaded Borgbjerg to carry a message from them recommending a "peace without compulsion", under which Germany would accept an independent Poland, lay no claim to the Courland of Lithuania, refrain from any further offensive against Russia (ignoring the victory at Stochod if necessary); and though hoping for minor frontier rectifications, would feel that

1 Vandervelde, Emile, Dans la Mêlée, Berger-Levrault, Editeurs, Paris, x919, p. 129; Sukhanov, N.N., The Russian Revolution, I917: A Personal Record, edited and translated by Joel Carmichael, Oxford University Press, London, 1955, p. 366.

2 Cumming and Petit, op. cit., p. 23; United States, Department of State, Papers Relating to the Foreign Relations of the United States: I9I 8: Russia, Government Printing Office, Washington, D. C., I931, Vol. I, Pp. 107-53; Russell, Charles Edward, Bare Hands and Stone Walls: Some Recollections of a Side-line Reformer, Charles Scribner's Sons, New York, 1933, pp. 346-70; Lansing, Robert, War Memoirs of Robert Lansing, Secretary of State, Rich and Cowan, Ltd., London, 1935, pp. 336-8. 
these could be settled in later negotiations since only the Balkans might cause difficulty. In return Russia would be expected to make a separate peace, thus allowing the German masses to return home to fight for Socialism. ${ }^{1}$

Borgbjerg's own reasons for going to Petrograd arose as follows. At the beginning of April, a month before the B.S.I. (Bureau of the Socialist International) appeal, the Danish Socialists decided that the time had come to act, and Stauning wrote to the B.S.I. to say that if it did not call a conference one would be arranged without its aid. On 7 April Borgbjerg was sent to Petrograd to get the support of the Soviet for this venture; Huysmans first discussed the question of an international Socialist conference at Stockholm with the Dutch Socialists on Is April. (E. H. Carr in The Bolshevik Revolution, 1917-1923, appears to have confused the invitations where he says that Borgbjerg carried to the Petrograd Soviet an invitation from the B.S.I. to attend an international Socialist conference at Stockholm.) ${ }^{2}$ After certain difficulties with visas, Borgbjerg reached Petrograd, spoke with the Soviet, and presented the German Socialists' peace proposals. The Soviet asked him if the Chancellor agreed to these proposals. According to Scheidemann, Borgbjerg replied, "I cannot say, but I think so. The German Social-Democrats are not the governing body and do not represent the majority in the Reichstag." Two days later a representative of the Soviet came to Borgbjerg and is reported to have said, "Your mission has succeeded. The Workers' and Soldiers' Council has decided - as has been announced in the Press - to issue invitations to a Conference. It will be easier for the English and French to take part. A clashing with the other conference is then out of the question." (The "other conference" was the Stockholm conference, for by this time, as we shall see, an invitation to a conference at Stockholm had reached Petrograd.) The German and Danish Socialists, on Borgbjerg's return, decided to support the Petrograd Soviet's initiative. ${ }^{3}$

$$
* * *
$$

1 Scheidemann, Philipp, Memoirs of a Social Democrat (hereafter called Scheidemann, "Memoirs..."), translated by J. E. Mitchell, Hodder and Stoughton, London, 1929, Vol. I, pp. 329-32.

2 Ibid, Vol. I, pp. 329-32; Vandervelde, “Three...”, op.cit., pp. 2ro-1; Cart, Edward Hallett, The Bolshevik Revolution, 1917-1923, Macmillan and Co., Ltd., London, 1953, Vol. III, p. 5 .

3 Scheidemann, "Memoirs...", op.cit., Vol. I, pp. 335-6; Manchester Guardian, The Manchester Guardian, Ltd., Manchester, Is May, I917, "Real" Russian Government: In Touch with German Social Democrats", p. s; Scheidemann, Philipp, Der Zusammenbruch, Verlag für Sozialwissenschaft, I 921 , Pp. I $52-3$. 
While these events proceeded, in Switzerland, the I.S.C. (International Socialist Commission, or Zimmerwaldians) were also active - and their activities caused the Central Powers some satisfaction. The I.S.C., after supporting the Russian Revolution by declaration, ${ }^{1}$ had decided to help the Russian Socialists in Switzerland to return to Russia. As these Socialists were "pacifists", their presence in Russia could only militate in favour of separate peace. Representatives of the various Russian Socialist parties belonging to the Zimmerwald organisation were brought together to approve Martov's suggestion to seek permission for their return home via Germany and Sweden, in exchange for which an equal number of Germans and Austrians interned in Russia should be freed. They sought by telegram the agreement of the Russian Provisional Government for this enterprise, but received no reply. Then the difficulties began.

Robert Grimm, the Secretary of the I.S.C., tried to get the Swiss Government (through Hoffmann, the member of the Federal Council in charge of the Political Department) to help with the plan, but assistance was refused on the ground that it would be considered a violation of neutrality by the Entente. Then Grimm approached the

Germans privately through Parvus to find out whether there was any objection in that quarter. ${ }^{2}$

By now the Russian émigrés were divided in their views on the proposal. The Bolsheviks wanted to leave immediately if the German Government would agree to allow them to cross Germany. For even before this Lenin, who realised the importance of being in Petrograd, had been trying to get back to Russia by any means he could contrive. He had first thought of paying smugglers to transport him through Germany to Russia, but had dropped this idea when the smugglers refused to carry him beyond Berlin. Then he considered a plan for travelling with false papers as a mute Swede, though Krupskaya pointed out the impractability of this scheme, and is reported to have said, "You might dream of the Cadets and curse them in your sleep, and they'd find out you are not a Swede." However, Lenin went so far

1 Archiv für die Geschichte des Sozialismus und der Arbeiterbewegung (hereafter called "Archiv..."), Veriag von C. L. Hirschfeld, Leipzig, editor: Carl Grïnberg, Vol. XII, p. 362 .

Scheidemann, "Memoirs...", op.cit., Vol. I, pp. 333-4; Vernadsky, George, Lenin, Red Dictator, translated by Malcolm Waters Davis, Yale University Press, New Haven, Connecticutt, 1931, pp. 152-3; Shub, David, Lenin: A Biography, Doubleday and Co., Inc., New York, I95 1, p. 182; Hoffman, General Max, Der Krieg der versäumten Gelegenheiten, Hase und Koehler, Leipzig, 1939, p. I 27; Carr, op. cit., Vol. III, p. I02; Beer, Max, Fifty Years of International Socialism, George Allen and Unwin, Ltd., London, I935, p. 195 . 
as to write to Hanecki in Stockholm about it. ${ }^{3} \mathrm{He}$ was therefore ready to accept any possible method of crossing Germany; but the Mensheviks felt that they should await the Russian Provisional Government's reply.

At this point, Lenin and Zinoviev, rather indiscreetly, published a circular informing the Russian émigrés of the Bolsheviks' decision to return and referring to Grimm's conversations with Hoffmann. In consequence Grimm had to withdraw from the affair and was replaced by Fritz Platten, who, with the aid of Paul Levi, organised the return of the Bolsheviks through Germany in an "extra-territorial" railway carriage. Paul Levi, who lived under the name of Hartstein in Geneva and Berne during the war, conferred with Lenin and Radek in Zuerich and then requested the Berne correspondent of the Frankfurter Zeitung to take up the question with the German Ambassador. The Ambassador checked with Berlin and the very next evening contacted Levi and asked him to see Lenin about the final arrangements for the trip. Lenin thereupon wrote out a series of conditions, including the one of the "sealed train" with Platten on board, all of which were accepted. ${ }^{1}$ In compensation for getting them across Germany, the Bolsheviks, once in Russia, agreed to try to get an equal number of Austrians and Germans returned to the Central Powers. ${ }^{2}$

The Germans did this believing Lenin to be "a more pushing fellow than Chkheidze and Kerensky" and hoping that he would gain control and press for immediate peace. Even Ludendorff justified the journey from a military standpoint. ${ }^{3}$ If no prisoners should be returned to them it was nonetheless to the advantage of the Central Powers to have an avowed "pacifist" like Lenin in Russia. This does not, of course, mean that Lenin was in any sense a "German agent" as has been alleged, though he received financial support from the German Government through Parvus for some time. ${ }^{4} \mathrm{He}$ was an opportunist

1 Shub, op. cit., pp. 180-1.

2 Ibid, pp. I82-3; Guilbeaux, Henri, Du Kremlin au Cherche-Midi (hereafter called Guilbeaux, "Du Kremlin..."), Librairie Gallimard, Paris, 1933, p. 106 and p. I27; Guilbeaux, Henri, Wladimir Iljitsch Lenin, Ein treues Bild seines Wesens (hereafter called Guilbeaux, "Wladimir..."), translated by Rudolf Leonhard, Verlag "Die Schmiede", Berlin, 1923, pp. 162-3.

${ }^{3}$ Fainsod, Merle, International Socialism and the World War, Harvard University Press, Cambridge, Massachusetts, I935, pp. 187-8.

4 Scheidemann, "Memoirs...", op.cit., Vol. I, p. 334; Rosenberg, Arthur, The Birth of the German Republic, I87I-r 18 , translated by Ian F. D. Morrow, Oxford University Press, London, 1931, p. I56; Ludendorff, General, My War Memoirs: 1914-1918, Hutchinson and Co., London, n.d., [1919], pp. 509-ro.

5 International Affairs, Royal Institute of International Affairs, London, April, I956, "German Foreign Office Documents on Financial Support to the Bolsheviks in 1917", George Katkov, pp. I81-9. 
willing to accept assistance from any quarter. By returning to Russia before the Mensheviks, he was alble to bring Bolshevik influence to bear before the Mensheviks were in a position to counteract it with their own propaganda; and thus he sowed the seeds for the November Revolution.

Nonetheless, when, on 6 April, he learned that the train was to leave for Germany the next day, Lenin telegraphed Henri Guilbeaux in Geneva, asking him to bring Romain Rolland and if possible two Swiss Socialists, Naine and Graber, to Berne. Lenin hoped that if he could get Romain Rolland's approval of the scheme, the very fact that a well-known French writer had lent his name to the affair would remove some of the stigma of being called a "German agent". However, Rolland thought the project foolhardy for just that reason and tried to get Guilbeaux to talk Lenin out of it. Guilbeaux refused and returned home to prepare to leave for Berne himself. There he found Fernand Loriot, a leader of the Zimmerwald Left in France, who agreed to accompany him.

That evening Zinoviev, Radek, Bronsky, Paul Levi, Inessa Armand, Lenin, Loriot, and Guilbeaux met in Radek's room in Berne and signed an explanation of the Bolshevik's action, which was later signed by others of the Zimmerwald Left, including, of course, Fritz Platten. ${ }^{1}$ The next day the Bolsheviks left for Russia. And shortly afterwards, the I.S.C., feeling strongly the shift of interest to the North, moved its headquarters to Stockholm. ${ }^{2}$

$$
* * *
$$

The March Revolution set not only the governments and the extremist Socialists into movement, but also caused the B.S.I. to act. Huysmans realised that the time had come to put an end to inaction; and that it was now possible for him to take more positive steps towards holding a full-scale international Socialist conference - a thing he had been unable to do since the outbreak of the war - without endangering the unity of the Socialist International.

On Is April, Huysmans and the Dutch section of the B.S.I. met at Laren in Holland where they decided to go to Stockholm. As the Belgian members, who with the Dutch made up the B.S.I., could not be present (Vandervelde was in Le Havre with the Belgian Government-in-exile, and Anseele and Bertrand were in the occupied zone of Belgium and unable to leave), Huysmans and the Dutch felt they had

1 Guilbeaux, "Wladimir...", op.cit., pp. 165-6; Guilbeaux, "Du Kremlin...", op.cit., pp. 130-3; Shub, op. cit., pp. I83-4.

2 Fainsod, op.cit., p. 149 . 
to act in the name of the Dutch Social-Democratic Labour Party alone and go to Stockholm on that basis. Once in Stockholm, with the aid of the Scandinavian parties, they planned to form an ad hoc committee to call an international Socialist conference, which would then ask for the collaboration of the Secretariat of the B.S.I. At this point differences arose. Huysmans felt certain that in time they would secure Russian Socialist collaboration in preparing the conference and that if they did, the French and British Socialists would find it very hard to refuse to come, for a refusal would be a snub to the Revolution. He, therefore, did not wish to extend invitations before he had gained Russian support. The Dutch section, however, did not want to go slowly, gaining the confidence first of one group and then of another, but hoped that the Revolution had changed the attitude of the official parties sufficiently for an immediate open invitation to be enough to bring them to Stockholm. Huysmans acquiesced and, on 22 April, at their request sent out invitations for an international Socialist conference to be held on Is May. ${ }^{1}$

Huysmans had, however, been right in believing that the appeal for an international Socialist conference could not be made hastily. On 26 April the British Labour Party Executive declined the invitation; ${ }^{2}$ and the next day the French majority Socialists did likewise. ${ }^{3}$ Vandervelde refused to come as soon as heard. 4 Then on 29 April the German Spartacists wrote to the Petrograd Soviet refusing to attend any conference at which the S.P.D. was present. ${ }^{5}$ And finally, the Bolsheviks, at their All-Russian April Conference, 7-12 May, refused to participate in a conference of "patriotic Socialists"."

By I May, both Huysmans and the Dutch committee were in Stockholm, and on 3 May, when the Danish and Norwegian delegates had also arrived, a Dutch-Scandinavian Committee was formed to promote and organise a full-scale international Socialist conference. At the first preparatory meeting, the Dutch-Scandinavian Committee

1 Comité organisateur de la Conférence socialiste internationale de Stockholm, (hereafter called "Stockholm"), Tidens Förlag, Stockholm, I9I 8, pp. vi-vii.

2 Brand, Carl F., British Labour's Rise to Power, Stanford University Press, Stanford University, California, 1941, p. 18 I.

3 Parti Socialiste (Section Française de l'International Ouvrière), Pendant la Guerre - Le Parti Socialiste, la Guerre et la Paix - Toutes les Résolutions et tous les Documents du Parti socialiste, de Juillet 1914 à Fin 1917 (hereafter called P.S.F., "Pendant la Guerre"), Librairie de l'Humanité, Paris, 1918 , pp. I62-5.

4 Louis, Paul, La Crise du Socialisme mondial, de la Ile à la IIIe Internationale, Librairie Felix Alcan, Paris, 1921, p. 64 .

5 Fainsod, op. cit., p. 152 ; “Archiv...”, op. cit., Vol. XII, pp. 370-2; Louis, op.cit., p. 64; Bevan, Edwyn, German Social Democracy during the War, George Allen and Unwin, Ltd., London, 1918, pp. 162-3.

6 Fainsod, op. cit., p. 1 so. 
made Huysmans secretary with the Swedish Socialist, Engberg, to help him, and then discussed the proposed conference. As it was now clear that the collaboration of the Russian Socialists was going to be necessary if the British and French Socialists were to change their minds, the committee was made a semi-permanent one, which would seek to transform itself into a Russian-Dutch-Scandinavian committee. It was also agreed to hold a series of "separate conferences", or meetings of the committee with individual party delegations, before the general conference met, since talks with de Brouckère of the Belgian P.O.B., who was on his way to Petrograd, had revealed that such "separate conferences" would be necessary; and the date of assembly for the main conference was put forward from is May to to June. Participation in the separate meetings would not commit the party concerned to attend the general conference. This was important, for the Belgian Socialists, and possibly others, objected strongly to a general conference, but felt that these separate meetings could do no harm and might do much good. ${ }^{1}$

The announcement of invitations to the Stockholm conference was greeted in the press of the Entente as a German manoeuvre, carried out by the Dutch Socialists, to get a separate peace with Russia, ${ }^{2}$ and at least the United States Government deliberately fostered this view. ${ }^{3}$ Many in the Central Powers, on the other hand, thought it was an Entente manoeuvre to corrupt the German Socialists and to encourage the strike movement which had followed the Russian Revolution; they felt, therefore, that German Socialists should be allowed to go only if they could achieve a separate peace with Russia. ${ }^{4}$ Faced with these hostile reactions the Dutch delegation issued a communiqué on s May denying any wish for a separate peace, but re-affirming its desire for a general peace based on the principles adopted by the International Socialist Congress held at Copenhagen in 1910 , and dissociating itself from all belligerent powers. ${ }^{5}$

At this point, 8 May, (as mentioned above in connection with

1 "Stockholm", op. cit., pp. viii-ix.

Ibid, p. x; The Times, The Times Publishing Co., Ltd., London, 7 June, 1917, "A German Peace Trap", p. 7; The Edinburgh Review, or Critical Journal, Longmans, Green, and Co., London, Harold Cox, editor, October, 1917 , "International Socialism and War", A. Shadwell, p. 233.

- United States, Department of State, Papers Relating to the Foreign Relations of the United States: 1917, Supplement 2: The World War, Vol. I (hereafter called U.S., "1917"), Government Printing Office, Washington, D.C., 1932, pp. 742-3.

- Lutz, Ralph Haswell, Fall of the German Empire, 1914-1918, translated by David F. Rempel and Gertrude Rendtorff, Stanford University Press, Stanford University, California, 1932, Vol. I, pp. 412-3; Price, op.cit., p. 50; Czernin, Count Ottokar, In the World War, Cassell and Co., Ltd., London, 1919, pp. 168-9 and p. 333.

s "Stockholm", op.cit., p. x. 
Borgbjerg's mission to Petrograd) the Petrograd Soviet itself decided to call for an international Socialist conference in a neutral country to discuss peace terms. ${ }^{1}$ On 9 May it released a public statement to this effect, which specified that the only organisations which should attend were those which agreed in advance to accept as a basis for discussion the principle of "peace without annexations or indemnities founded upon the self-determination of nations", and to be brought about by mass action of the international working class in accordance with binding commitments to be undertaken at "Stockholm". The Petrograd Soviet stated, moreover, that, before being admitted to the conference, the various organisations must abandon their policies of "civil peace". ${ }^{2}$ Though at that time this programme was completely unacceptable to the majority Socialists, when they later agreed to attend the conference they had accepted it with a single, but crucial, exception: they refused to commit themselves in advance to treat the decisions of the conference as binding upon them.

This programme, however, was on the whole acceptable to the Zimmerwald movement, of which the majority of the Petrograd Soviet were members. Therefore, this new invitation changed the situation for the I.S.C., and made holding a third conference of Zimmerwaldians far more important, especially as the I.S.C. had been asked by Huysmans and the Dutch Committee to participate in the preparatory work for Stockholm, for it was hoped that all who had belonged to the pre-war Second International would be represented at it. However, in accordance with the decisions taken at Kienthal, as a result of Lenin's and Zinoviev's efforts to get the Zimmerwald movement to break completely with the Second International, the I.S.C. could not accept outright, but only after a preliminary meeting of its own members. Robert Grimm, for the Commision, therefore, sent on ro May a circular to the member organisations notifying them of the international conference organised by the Dutch-Scandinavian Committee and of its postponement to ro June, pointing out that, in consequence, the third Zimmerwald conference would meet in Stockholm on 3 I May to discuss peace and the position to be taken up vis-à-vis the conference called by the Dutch. ${ }^{3}$

Before the Petrograd Soviet had issued its invitation to an international Socialist conference the decision of the Bolsheviks and

1 Golder, Frank Alfred, Documents of Russian History, I914-1917, translated by Emanuel Aronsberg, The Century Co., New York, 1927, pp. 339-40.

${ }^{2}$ Fainsod, op.cit., pp. x 52-3; “Archiv...", op.cit., Vol. XII, p. 372.

3 Gankin, Olga Hess, and H. H. Fisher, The Bolsheviks and the World War: The Origin of the Third International, Stanford University Press, Stanford University, California, I940, p. 724; “Archiv...", op. cit., Vol. XII, pp. 363-4; Fainsod, op. cit., pp. 149-50. 
Spartacists to boycott the conference called by the Dutch-Scandinavian Committee, would have made participation by the I.S.C. very difficult. But now Stockholm enjoyed the support of the new Russian democracy, and of a majority within the Zimmerwald movement. Though later, as the Bolsheviks strengthened their position in Russia and thereby their position in the I.S.C., and as the general enthusiasm for Stockholm waned as the summer passed with only delays and no conference forthcoming, the Bolshevik opposition to it assumed greater importance.

The Dutch-Scandinavian Committee welcomed the parallel initiative of the Petrograd Soviet and prepared to meet the Russian delegation due to arive shortly in Stockholm with a view to working out a joint programme of some sort. On I 8 May, they received a telegram of support from the Mensheviks ${ }^{1}$ (who, together with the SocialRevolutionaries, formed the majority of the Petrograd Soviet), which cleared up any possible danger of a conflict between the two conferences. Now it only remained to gain the support of the British and French Socialists and to get the governments to agree to grant passports to the delegates. These were admittedly formidable tasks, but the backing of the Soviet would help.

The governments, too, received this announcement of the Petrograd Soviet with interest. On 2 I May the British War Cabinet discussed Stockholm and whether to send Henderson to Petrograd. The success of the submarine warfare was reaching disastrous proportions and it seemed that Britain might only be able to hold out for a few more months. Nivelle's offensive had failed only a few weeks previously and the French army was rent with mutinies and could not be relied on. A negotiated peace might be the best solution before things got worse or the extent of German naval success and French military disruption became apparent to the Central Powers - and Lloyd George was, therefore, not unpleased with Stockholm. It could offer an apparently bold and dramatic way out of a desperately threatening stituation and provide a method of avoiding starvation, humiliation, and defeat without making it necessary to own up publicly to the dangers the country was facing. Such an admission would probably have led to the collapse of his government and to new elections, ${ }^{2}$ and, moreover, Lloyd George never entirely lost his early radicalism and some at least of the principles of Stockholm must have appealed to the Celtic rebel in him. In any case he would not be committed to the Socialists' decisions; nothing would be lost by tacitly encouraging Stockholm. A telegram was sent to Albert Thomas, then French

1 "Stockholm", op. cit., p. xii; Fainsod, op. cit., p. I 34.

2 U.S., "I917", op.cit., p. 118. 
Ambassador in Russia, to ask him to encourage the Socialist deputations from Allied countries to support Stockholm. Albert Thomas cabled his agreement in reply, stating that he had already advised the French Prime Minister in similar terms, and adding that "the effect would be really deplorable on the Russian Socialists if the French and British Socialists were absent and the German Socialists present." 1 On 26 May, the British War Cabinet decided to send Henderson on a mission to Russia, leaving the very next day.

Almost immediately after these events came a dramatic volte-face of the S.F.I.O. at a meeting of the National Council of the party in Paris, 27-29 May. When the meeting opened, the patriotic majority was against going to Stockholm, the pacifist minority for it; but during the afternoon of the $27^{\text {th }}$ Cachin and Moutet unexpectedly arrived back from Petrograd convinced of the need for Stockholm. Both addressed the conference, which was stupefied. A telegram then arrived from Vandervelde pointing out the need for "separate conferences" at Stockholm, though he did not approve of the general conference. ${ }^{2}$ The Council meeting adjourned, and when it re-assembled voted unanimously, though with about a dozen abstentions on the right, both for the settlement of the Alsace-Lorraine problem by plebiscite (as the Russian Soviet wished) and for Stockholm. For the first time since the war, "The Internationale" was sung outside in the streets of Paris. $^{3}$

On 29 May, Lloyd George received Ribot, then French Premier and Foreign Minister, at Downing Street to discuss affairs in Greece. Lloyd George told Ribot that he intended to let British Socialists of all opinions go to Stockholm and Petrograd. Ribot would not commit the French Government; personally he was not opposed to French Socialists going to Stockholm, but if he allowed them to, his government might fall in face of non-Socialist criticism in the French Chamber. ${ }^{4}$ However, events soon precipitated a decision: on 3 I May

1 Hamilton, Mary Agnes, Arthur Henderson, A Biography, William Heinemann Ltd., London, 1938, pp. 130-2; Williams, Francis, Fifty Years' March: The Rise of the Labour Party, Odhams Press, Ltd., London, 1949, Pp. 265-6.

2 Louis, op. cit., p. 66; The Times, op. cit., 29 May, 1917, "French Socialists and Russia", p. 5. 3 Manchester Guardian, op.cit., 2 June, 1917 , "The French Socialists' Decision", p. 5; P.S.F., "Pendant la Guerre", op. cit., p. 167; Fainsod, op. cit., pp. 134-5; "Stockholm", op.cit., pp. xvi-xvii; Bourgin, op.cit., pp. 214-8; The Times, op.cit., 30 May, 1917, "Ftench Socialists for Stockholm", p. 7.

4 ed. Lennox, Lady Algernon Gordon, The Diary of Lord Bertie of Thame, 1914-1918, Hodder and Stoughton, London, I924, Vol. II, pp. 130-3; Ribot, Alexandre, Letters to a Friend: Recollections of my Political Life (hereafter called Ribot, "Letters"), translated by Herbert Wilson, Hutchinson and Co., London, n.d. [1926], p. 236; Ribot, Alexandre, Journal d'Alexandre Ribot et Correspondances inéditées, Igr4-1922, Librairie Plon, Paris, 1936, pp. I36-8. 
the National Council of the S.F.I.O. appointed Longuet and Renaudel to go to Petrograd, via Stockholm where they were to meet the DutchScandinavian Committee, and they at once applied for passports. On I June, Ribot, in an open session of the Chamber of Deputies, stated that the Council of Ministers agreed unanimously that passports should not be issued for Stockholm. He added that he would be glad to grant passports for a visit to Petrograd once Stockholm ceased to be an issue. Then the Chamber, at Cachin's request, went into secret session on I June and on 4 June. ${ }^{1}$ On 6 June, however, Ribot repeated before the Senate, in both open and secret sessions, his refusal to grant passports to the Socialist delegates. ${ }^{2}$ The French Government feared that they would be held responsible for any results of Stockholm if passports were granted; and they also took account of the likely effects that such a peace conference might have on the already weakened morale of the troops - it might give rise to dangerous illusions; and, perhaps, unlike Russian soldiers, French troops would fight better for victory than for peace. ${ }^{3}$

On 24 June, Albert Thomas arrived back in Paris. In spite of the opinions he had voiced in his telegram to Lloyd George a month earlier, he was now suspicious of the Stockholm project. ${ }^{4}$ He suggested to the S.F.I.O. Parliamentary Group, on 2 July, that it should reply to the questionnaire on peace terms sent out by the Dutch-Scandinavian Committee, but should not meet the committee in a "separate conference", and proposed that a delegation should go directly to Russia to press for the conditions he believed necessary in order to ensure that the French would not be faced with German-Russian collusion at any conference which might be held. ${ }^{5}$ Nonetheless, as the party had already made its decision, he publicly supported Stockholm, and this, coming from a Minister, was not without effect, though the government still refused to grant passports.

$$
* * *
$$

Meanwhile, on I June, the Executive Committee of the Petrograd Soviet again endorsed the Stockholm project, and set a date, $8 \mathrm{July}$, for

1 France, Débats Parlementaires: Compte Rendu in Extenso, Chambre des Députés, Session Ordinaire de I917, Journal Officiel du 2 juin, I917, Pp. 1323-5.

2 France, Débats Parlementaires: Compte Rendu in Extenso, Senat, Session Ordinaire de I917, Journal Officiel du 7 juin, 1917, pp. 5 I I-5.

"Ribot, "Letters", op. cit., pp. 236-7.

- Noulens, Joseph, Mon Ambassade en Russie Soviétique, 1917-1919, Librairie Plon, Paris, 1933, Vol. I, p. 58; Lennox, op.cit., Vol. II, p. 181; interview with Prof. Paul Mantoux, who was attached to the French Embassy in London.

- Bourgin, op.cit., pp. 230-I. 
the conference to meet, ${ }^{1}$ but it was not until a month later that a Russian delegation reached Stockholm, and the final arrangements were not made until i I July to form the Russian-Dutch-Scandinavian Committee to organise the general conference. However, the DutchScandinavian Committee had meanwhile carried on with a marathon of "separate conferences" - the first of which was held at the end of May and the last on to November. All parties of importance, except the American and the French, managed to be present at some time, officially or unofficially; and even these two parties tried to attend. All parties also had sent or brought memoranda on peace terms in answer to the questionnaire sent out by the Dutch-Scandinavian Committee. ${ }^{2}$

The momentum of events was now building up. It looked as if Huysmans' wish to hold an international Socialist conference would be fulfilled and representatives from both the Allied and the Central Powers would be brought together to discuss the conditions in which peace could be realised. The preparatory work had already gone far beyond anything achieved by earlier attempts to hold an interbelligerent conference since the beginning of the war. The only outright refusals to attend came from the Spartacists, the Bolsheviks, and the Rumanian Socialist Party ${ }^{3}$ - all Zimmerwaldians, and so far not major influences in the drama.

$$
* * *
$$

The position of the I.S.C. - the Zimmerwaldians - was however to become of critical importance. If the key to Stockholm lay in Russia's attitude, the key to Russia became the Petrograd Soviet. And Zimmerwaldians - Bolshevik, Menshevik, and Social Revolutionary - contended for the Soviet. The tensions which developed in the I.S.C. had their counterparts in the Soviet, and these largely determined the fate of Stockholm and also of Russia. It is to this interplay, from which Lenin ultimately emerged supreme, that we now turn.

As already noted, the Bolsheviks had adopted Lenin's view and decided in April not to attend any gathering sponsored by "patriotic"

1 "Stockholm", op.cit., pp. xvii-xviii; Fainsod (op.cit., p. 136) misreports this itern by saying that the Dutch-Scandinavian Committee sent out this statement.

2 "Stockholm", op. cit., pp. xiv-xv and pp. xviii-xix.

3 The Rumanian Socialists refused to come because the German occupation authorities proposed that they should. They, therefore, believed the conference to be organised by the Germans, and instead asked that an inter-Allied Socialist conference should be held in Petrograd. Interview with Serban Voinea, former President of the Rumanian Socialist Party, and former Rumanian Minister at Berne; l'Humanité, Journal Socialiste, S.F.I.O., Paris, editor: Pierre Renaudel and later Marcel Cachin, 9 September, 1917, "Les Socialistes roumains proposent une Conférence interalliée à Petrograd". 
Socialists, though they turned down his proposal to break even with Zimmerwald, except in so far as necessary "to gather information". Lenin recognised that if Stockholm succeeded, the "floating" centre of Socialist opinion - neither "patriotic" nor "revolutionary" - which had previously supported the Zimmerwald movement, would return to the Socialist International, and that Huysmans would succeed in keeping the International together. He realised that in the revived International he and his supporters would again become an impotent minority, a small "ginger group" and that the opportunity given to him by the Russian Revolution and his return to Petrograd would be lost, at least in international affairs and possibly also in Russia itself. In the hope of forestalling such a development and retaining the initiative, he worked consistently against Stockholm and sought the establishment of a Third International, since he believed it was necessary to destroy old loyalties and to replace Zimmerwald with a new International led by the Bolsheviks. In April, however, the Bolsheviks were not yet disposed to follow Lenin's devious tactical genius the whole way and wished to remain united with their comrades of the war years in the I.S.C. ${ }^{1}$

Although three parties of the Zimmerwald movement had already come out against Stockholm, the organisation as a whole had not yet pronounced its views. By late May two members of its Executive, Angelica Balabanoff and Robert Grimm, were in Petrograd. Angelica Balabanoff had left Zuerich in early May travelling in the second of the "sealed trains" crossing Germany, and arrived in Petrograd on 20 May. ${ }^{2}$ Robert Grimm was considered pro-German by the Entente and so, although he arrived in Stockholm on 24 April, he only reached Petrograd a month later after the Menshevik Ministers agreed to vouch for him. (In fact, news of his permission to enter Russia did not reach him until after he had already crossed the Russian frontier with an escort from the Helsingfors Soviet, which had accepted the responsibility of getting him safely to Petrograd.) ${ }^{3}$

Grimm and Angelica Balabanoff attended the All-Russian Menshevik Conference on $20 \mathrm{May}$, which agreed to take part in both the international Socialist conference and the third Zimmerwald conference to be held at Stockholm, Grimm taking an active part in the discussions. They also attended meetings of the Executive Committee of the Soviet

\footnotetext{
1 Fainsod, op.cit., pp. 150-1; Trotsky, Leon, The History of the Russian Revolution, Victor Gollanez Ltd., London, I934, Pp. 34I-2; Carr, op. cit., Vol. III, p. 570.

2 Balabanoff, Angelica, Erinnerungen und Erlebnisse (hereafter called Balabanoff, “E. und E."), E. Laubsche Verlagsbuchhandlung G.m.b.H., Berlin, 1927, p. 138; Gankin and Fisher, op. cit., p. 615.

s Gankin and Fisher, op.cit., p. 6rs.
} 
where Stockholm was again discussed; and finally they met the Russian Zimmerwaldians ${ }^{1}$ on 28-29 May. There opinion over attending Stockholm was divided and the decision was left to be taken at the third Zimmerwald conference. Lenin and Zinoviev sought to take the opportunity afforded by the presence of members of the Bureau of the I.S.C. in Petrograd to influence the Soviet's attitude to Russian domestic politics. He asked the Zimmerwaldians to condemn then and there the participation of Russian Socialists in the Provisional Government; but the majority at the meeting, though sharing Lenin's views, agreed that a decision could only be taken after all member groups had been consulted, so the question was dropped. In fact the only positive decision taken was the agreement that the I.S.C. should issue another invitation for a third Zimmerwald conference to meet three days before whatever date was finally fixed for the general Stockholm conference. ${ }^{2}$ This decision was partly in the nature of a vote of confidence in Robert Grimm for the invitation he had already sent out, but also, the invitation of the Petrograd Soviet had made everyone take the question of participating in the general conference at Stockholm more seriously.

After these meetings at the end of May, Robert Grimm stayed on in Petrograd to encourage the Russian workers to support the Socialist "minority" (i.e. Zimmerwaldian and pacifist) groups in other belligerent countries in hope of ending the war more quickly. By spreading pacifist propaganda, he naturally incurred the disfavour of the Entente Governments, including that of the Russian Provisional Government, then trying to launch a new offensive. Furthermore, he had already won disfavour in the eyes of the Bolsheviks who considered him, on doctrinal grounds, an ally of Haase and Kautsky. The Bolsheviks felt that he had let them down personally by his failure to get them out of Switzerland and into Russia; and, finally, they disapproved of his support of Stockholm. They were not, therefore, altogether displeased when in the middle of June the Russian Government deported Grimm as a German agent on the strength of a telegram he had received from Hoffmann, the Swiss Foreign Minister, which outlined a German offer of separate peace and gave an assur-

1 Present at this meeting were: Balabanoff and Grimm for the I.S.C.; Bobrov of the Social Revolutionary Internationalists; Zinoviev, Lenin, and Kamenev of the Bolsheriks; Abramovitch of the Bund; Lapinsky of the Polish Socialist Party (Levitsa); Ryazanov, Trotsky, and Uritsky of the "Mezhraionka"; Rakorsky of the Rumanian Social-Democratic Party; and Bienstock, Martov, Martynov, and Larin of the Menshevik Internationalists. Gankin and Fisher, op. cit., pp. 615-6; Fainsod, op.cit., pp. 153-4; "Archiv...", op.cit., Vol. XII, pp. 365-6; Balabanoff, "E. und E.", op.cit., Pp. I48-5I; Balabanoff, Angelica, My Life as a Rebel (hereafter called Balabanoff, "My Life..."), Hamish Hamilton, London, I938, pp. $174^{-6}$. 
ance that Germany would not start an offensive as long as there was a chance of such a peace with Russia. ${ }^{1}$ (Grimm subsequently showed that the telegram came in answer to one of his own and cleared himself of the charge of being a German agent.) Grimm's usefulness to the Zimmerwald movement was at an end, and on his return to Stockholm, he resigned from the I.S.C., and was replaced by three Swedish Left Socialists, Höglund, Carleson, and Nerman.

Shortly after Grimm's departure from the scene, Angelica Balabanoff had to return from Petrograd to Stockholm to help the Swedes carry on the I.S.C.'s work, ${ }^{2}$ which at this date was largely concerned with trying to formulate a definite Zimmerwald attitude towards Stockholm. If Stockholm had in fact been held the Zimmerwald movement would probably have been rent asunder on the issue of Stockholm; but as it was, the problem of reconciling the inconciliable made little difference, for Socialist opinion had already accepted as a fait accompli the defeat of the Stockholm venture before the third Zimmerwald conference met and had turned its interests first to the efforts of the Entente Socialists to write a memorandum on war aims, and later to the victory of the Bolsheviks in the November Revolution.

On 3 July, a delegation of seven members of the Petrograd Soviet arrived in Stockholm. Three of them, Goldenberg, Rosanov, and Smirnov, ${ }^{3}$ met with the I.S.C. on 3 July; in the following week, the entire delegation - Axelrod, Ehrlich, Goldenberg, Panin, Rosanov, Rousanov, and Smirnov - met the Dutch-Scandinavian Committee; and on 9 July Rosanov, Rousanov, and Ehrlich met the I.S.C. These meetings were aimed at uniting the three separate initiatives - DutchScandinavian, Soviet, and I.S.C. - for a Stockholm conference into a single, united appeal. With the strength of the entire Socialist movement behind it, Stockholm could become a powerful force for peace. Their ultimate failure in this effort was substantially due to the growing influence of Bolshevik opposition to the whole idea of Stockholm both in the Petrograd Soviet and also in the Zimmerwald movement. Moreover, Höglund, Carleson, and Nerman, who had replaced Grimm on the I.S.C., were, in point of doctrine, to the left of Grimm, and therefore more opposed to any compromise with the moderate Socialists than he had been. Their influence added to the importance

1 L'Humanité, op.cit., 18 June, 1917, "Une mesure d'expulsion contre Grimm", p. 3; Kerensky, Alexander F., The Catastrophe: Kerensky's Own Story of the Russian Revolution, D. Appleton and Co., New York, 1927, p. 208.

2 Gankin and Fisher, op.cit., pp. 616-29; Fainsod, op.cit., pp. I54-5; Balabanoff, "My Life...", op.cit., pp. 177-9; Balabanoff, "E. und E.", op. cit., pp. I $57-63$.

${ }^{8}$ Fainsod (op.cit., p. 155) says Zinoviev was the third delegate; Gankin and Fisher (op.cit., p. 630 and p. 637) say Smimov. It is unlikely that Zinoviev, a Bolshevik, adamant against the conference, was a delegate for the Petrograd Soviet. 
of the Bolsheviks and meant that the effective leaders of the I.S.C. itself were now less well disposed to Stockholm, which aimed, among other things, at effecting precisely such a compromise.

Yet most of the Zimmerwaldians - and among them the U.S.P.D. (Unabhängige Sozialdemokratische Partei Deutschlands), the British I.L.P., the French "minority" Socialists, the Italian P.S.I., and the Swiss Socialist Party - were not disposed to take up extreme positions; indeed, in their view, the Zimmerwald movement had been created to "ginger" the B.S.I. and the right-wing majority Socialists into holding just such a conference as Stockholm to bring peace and to re-unify the international Socialist movement. Respect for the Bolsheviks had increased, but pacifism rather than revolutionary ardour was still the motivating force among most of the supporters of the Zimmerwald movement, and though they disagreed with the right-wing Socialists on many points, the attitude of these right-wing Socialists itself was being changed by the compelling example of the Russian Revolution. In any case, Stockholm certainly seemed to most of the Zimmerwaldians to offer the best chance for peace and for a platform from which to preach peace. They wanted a strong and united Socialist movement, and were to go on seeking it long after all others had given up hope that it could be achieved, long after the Third International had been formed, and the Second International had become ardently antiBolshevik, and long after the long-suffering Huysmans had abandoned his efforts to bridge the rifts.

The meeting of 3 July between the I.S.C. and the Russian delegates was a very agitated one. The Left Zimmerwaldians were furious at what they regarded as a compromise on a point of principle made by the Petrograd Soviet to ensure that the right-wing Socialists would come to Stockholm. For when - in reply to the Soviet's original invitation to Stockholm in May, which called for peace without annexations and indemnities based on self-determination, and demanded that Socialists should bring an end to the policy of "civil peace" before going to Stockholm - Albert Thomas, Vandervelde, and de Brouckère had asked for clarification of the term "annexations", and had stated that as long as England, France, and Belgium were fighting a defensive war, "civil peace" remained necessary, the Executive Committee of the Soviet had promptly written back that it did not regard the renunciation of "civil peace" as a necessary condition for attending the conference.

After a short discussion on the draft agenda prepared by the I.S.C. for the third Zimmerwald conference (in which the Soviet delegation refused to take part, saying that it had come to discuss Stockholm), Radek began the more general debate by referring to the letter from 
Thomas, Vandervelde, and de Brouckère and asked the Soviet delegation for a clear and precise statement of its intentions. Goldenberg replied that the way should be left open for co-operation with the right-wing Socialists, and that a break with the policy of "civil peace" should not be made a pre-condition of attendance at Stockholm; the parties represented should, however, be committed in advance to carry out the decisions of the conference, whatever they might be. Radek, who was supported by Kirkov, remained unimpressed and retorted that the importance of the class struggle had not been sufficiently emphasised, and that the Left Zimmerwaldians considered a general conference with right-wing Socialists to be totally unacceptable, and that the Soviet was actually impeding the revolutionary movement in Western Europe by its efforts to call such a conference. Then after the Soviet delegates had again replied, the U.S.P.D. delegates announced their decision to take part in the Stockholm conference. Angelica Balabanoff stated that, while she personally opposed participation, only a full meeting of the Zimmerwald organisation could decide the question, and the meeting thereupon broke up without reaching any firm conclusion. But Radek, for the Bolsheviks, left no room for doubt, "In no case are we going to the conference", he said.1

However, the I.S.C. continued the discussion the next day without the Soviet delegates and it was again agreed to hold the third Zimmerwald conference a few days before the general Stockholm conference. But if that conference should not meet before is September, the Zimmerwald conference would be convened as soon as possible thereafter. ${ }^{2}$ The Soviet delegation was not present because it had begun conversations with the Dutch-Scandinavian Committee.

***

The Soviet delegation's talks with the Dutch-Scandinavian Committee in the following days, 4-I I June, fared more promisingly. (The whole delegation attended these meetings whereas only three members had joined in the talks with the I.S.C., indicating the - quite natural relative importance the Soviet then attached to these two bodies.) There were serious divergencies and difficulties to be overcome in the Soviet-Dutch-Scandinavian talks; but there was not a deliberately disruptive revolutionary faction such as existed in the I.S.C. to undermine the broad common purpose for which they met.

1 Gankin and Fisher, op.cit., pp. 637-8; Balabanoff, "My Life...", op.cit., pp. 182-3; Balabanoff, "E. und E.", op. cit., pp. I65-6; Fainsod, op cit. pp. I s5-6.

2 Gankin and Fisher, op.cit., p. 630; Fainsod, op.cit., p. 156; “Archiv...", op.cit., Vol. XII, pp. 372-4; Balabanoff, "My Life...", op. cit., p. I 83 . 
The Dutch-Scandinavian Committee wanted to write a memorandum on peace terms, based on the results of the various "separate conferences" they had already held, to be presented at the general Stockholm conference as a basis for its deliberations. The Russians, however, felt that any such attempt to present the conference with predigested decisions would be quite wrong. The Dutch-Scandinavian Committee accepted this, but would not definitely accept the Russians' desire to make the conference decisions binding upon the participants: Branting and Vliegen both pointed out that it would make it difficult or impossible for the French and British parties to come at all. Troelstra added that a party could only pledge itself to carry out those decisions for which it had voted as its members would in any case not follow international decisions with which they disagreed. The Russians, however, still wished participants to be pressed to commit themselves and requested that this point should be stressed in the "separate talks" and in the invitations to the conference.

The most controversial question discussed was whether to invite the I.S.C. to take part in the preparatory work of the conference, though it was agreed by all that the minorities as well as the majorities of the various national parties should be represented at the conference itself. The Dutch-Scandinavian Committee proposed that the Russians should simply join them to form a Russian-Dutch-Scandinavian Committee, but the Russians wanted a three-part commission including the I.S.C. if it agreed. The I.S.C. was, however, still unable to decide whether or not it favoured Stockholm at all, and the Russian delegation therefore undertook to hold yet another meeting with it.

This meeting took place on 9 July between Balabanoff, Carleson, and Höglund of the I.S.C., and Rousanov and Ehrlich of the Russian delegation. There was a good deal of inconclusive talk and many questions and answers, in the course of which the Soviet delegates pointed out that in fact the majority of the Zimmerwald parties had already expressed a desire to participate in the general conference. Angelica Balabanoff retorted that any decisions made before the full Zimmerwald conference were "rude violations of discipline". The meeting ended on this note, and the Russians reported back to the Dutch-Scandinavian Committee that the I.S.C. had promised a decision for the next day. The next day no decision was forthcoming so that the Russians again approached the I.S.C. Though they still received no formal answer, they were told that if any were given it would be "no". Still determined to win over the I.S.C., the Russian delegation tried once more to arrange a meeting, but failed because two of the I.S.C. members had already left Stockholm.

Meanwhile, on I I July, the Russians reached an agreement to form a 
joint committee with the Dutch-Scandinavian Committee. That same day the new Russian-Dutch-Scandinavian Committee issued a manifesto containing yet another invitation to Stockholm which postponed the conference to is August. This invitation said little that was new, but it did address a special invitation to the trade unions to come. Though such an invitation had been implied in previous statements, it was here made specific in order to avoid any possible criticism or manoeuvre. Also a provisional agenda for the conference was included, which was so worded that no issue, however delicate, would be out of order. ${ }^{1}$

The Russian delegation issued a supplementary declaration expressing its regret that the I.S.C. refused to co-operate in the preparatory work of the Stockholm conference, more especially as all the Russian Socialist parties belonged to it; and announced that a Zimmerwald conference would be held in Stockholm five days before the general conference. ${ }^{2}$ The Russians attached great importance to the representation of the minorities (especially of the Zimmerwald movement) at a general conference, and, therefore, decided to attend the third Zimmerwald conference to repeat once more the invitation to Stockholm. ${ }^{3}$

The Dutch-Scandinavian Committee had organised the "separate conferences"; the new joint committee was to organise the general conference. Thus after the talks in Stockholm were over, the Russian delegation agreed to undertake a circular tour of the various Allied countries, leaving the original Dutch-Scandinavian Committee to continue the "separate conferences" in Stockholm. The Russians proposed to complete the work, begun by Wibaut and Vliegen, of bringing the Socialist parties of the Entente countries around to the idea of holding an international Socialist conference, ${ }^{4}$ for the British, Italian, and Belgian parties had not yet decided to come, though it seemed likely that they would accept.

(to be concluded in the next issue)

1 "Stockholm", op. cit., pp. xix-xx and pp. 484-s.

Ibid, p. 486.

Gankin and Fisher, op. cit., pp. 637-40.

" "Stockholm", op. cit., p. xx. 